Article

\title{
Evaluation of an Environmental Education Program Using a Cross-Sectoral Approach to Promote the Sustainable Use of Domestic Drains
}

\author{
Juan-Jesús Martín-Jaime, Leticia-Concepción Velasco-Martínez and Juan-Carlos Tójar-Hurtado *D \\ Faculty of Education Science, University of Malaga, 29071 Malaga, Spain; jjmatin@uma.es (J.-J.M.-J.); \\ leticiav@uma.es (L.-C.V.-M.) \\ * Correspondence: jctojar@uma.es
}

check for updates

Citation: Martín-Jaime, J.-J.; Velasco-Martínez, L.-C.;

Tójar-Hurtado, J.-C. Evaluation of an Environmental Education Program

Using a Cross-Sectoral Approach to Promote the Sustainable Use of Domestic Drains. Sustainability 2021, 13, 12041. https://doi.org/ $10.3390 /$ su132112041

Academic Editors: David Molero and Inmaculada García-Martínez

Received: 29 September 2021

Accepted: 27 October 2021

Published: 31 October 2021

Publisher's Note: MDPI stays neutral with regard to jurisdictional claims in published maps and institutional affiliations.

Copyright: (c) 2021 by the authors. Licensee MDPI, Basel, Switzerland. This article is an open access article distributed under the terms and conditions of the Creative Commons Attribution (CC BY) license (https:/ / creativecommons.org/licenses/by/ $4.0 /)$.

\begin{abstract}
The discharge of hygienic waste down domestic drains has become a socio-environmental problem that is causing serious damage to aquatic ecosystems and wastewater management systems. In this paper, we report the results of our study to determine the effectiveness of an environmental education (EE) program to raise awareness of this problem among primary school students. A longitudinal study was carried out using a survey methodology. A questionnaire, including Likertscale items, was designed $(n=4362)$. A study of the reliability and validity of the measure was carried out using validations conducted by experts, Cronbach's Alpha coefficient, factor analysis, and the categorical analysis of principal components (CATPCA). The analyses showed that there were significant differences between the educational cycles of primary education and two different versions of the program. For example, a second version of the EA program, with a more positive approach, produced an improvement in the acquisition of knowledge, behaviors, and attitudes regarding the development of good habits concerning the use of household drains. The conclusions show the suitability of this cross-sectoral EE program for actively involving students and their families in the proper management of household hygienic waste.
\end{abstract}

Keywords: aquatic ecosystems; environmental education; values; pro-environmental behaviour; hygienic waste

\section{Introduction}

Plastic hygienic waste's being improperly disposed of in domestic toilets has significant environmental and economic consequences. According to Barrows et al. [1], plastics degrade progressively into increasingly tiny fragments, eventually forming plastic microparticles (microplastics) that enter river and marine ecosystems, mainly through sewage effluents. Frias and Nash [2] established that microplastics can be considered synthetic solid particles, with at least one dimension varying between $0.1 \mu \mathrm{m}$ and $1 \mathrm{~mm}$. To differentiate them by shape, the following terms are often used: "bead" (spherical plastic), "fiber" (plastic threads), and "fragment" (irregular particles). Microplastic fibers may constitute up to $91 \%$ of all plastics collected in seawater samples worldwide and are, therefore, currently considered emerging pollutants.

The document "Microplastics in drinking water", prepared by the Spanish Association of Water Supply and Sanitation [3], points out that $95 \%$ of the total microplastics from household drains can be eliminated in wastewater treatment plants, but also indicates that their separation produces an economic cost overrun representing between $10 \%$ and $18 \%$ of the public cost of wastewater treatment. Similarly, the European Union estimates an annual additional cost of between 500 and 1000 million euros for the disposal of plastic waste contained in wastewater in the treatment plants in its territory.

Likewise, this type of hygienic plastic waste can cause serious damage to marine ecosystems and the health of citizens. The socio-environmental repercussions related to 
the generation of plastic waste are becoming increasingly widespread. As some authors have warned $[4,5]$, microplastic waste is abundantly distributed throughout the seas and oceans, producing environmental alterations, and its contaminating effect spreads throughout the food chain, also affecting human consumption. These pollutants do not remain near the points of discharge because the horizontal and vertical movements of water masses, mainly caused by currents, tides, and waves, spread plastics along coasts and throughout oceans. Lusher [6] detected abundant synthetic microplastic fibers and particles, from 1 to $5000 \mu \mathrm{m}$ in diameter, in coastal, open-ocean, and even polar marine environments. Microplastics have a greater influence on marine life in coastal waters, as most marine species concentrate their populations in underwater continental margins. Lindeque et al. [7] conducted a study on the coast of the North Atlantic Ocean; their results show a concentration of 3700 microplastic particles per cubic meter. According to Roch-man et al. [8], microplastics cause persistent pollution with negative environmental and economic consequences in coastal habitats around the globe. In addition, the existence of a great diversity of marine species that act as biological concentrators of microplastics in suspension should be taken into account [9]. These are filter-feeding organisms, which include species that are consumed by humans worldwide. For example, clams (Venus gallina) and mussels (Mytilus edulis) act as bioaccumulators of microplastics in the environment, as they feed by filtering water to capture the microalgae around them. Consequently, if the marine environment is contaminated by microplastics, these animals also ingest them and accumulate them in their bodies, thereby posing a high risk to food safety [10]. Likewise, Nelms et al. [11] indicate that the microplastics found in the stomach contents of marine mammals have been ingested by way of mollusks and fish. Therefore, to assess the impact of plastics on marine ecosystems and human health, it is essential to study the relationship between the ingestion of microplastics by species and the amount of plastics in the sea [12]. In this regard, Hantoro et al. [13] also indicate that data on the levels of microplastics in marine species and their toxicological effects on health are still limited due to the lack of standardized analytical methods for performing comparisons between study results.

Wet wipes, ear buds, preservatives, sanitary napkins, dental floss, and contact lenses are examples of sanitary or personal hygiene products that are flushed down the toilet. The toilet is considered a gateway for various small waste products composed of plastics, which are consumed quickly and frequently and reach coastal and river environments through domestic drains. Specifically, wipes are one of the products that most damage the sewage- and water-purification systems and, in most cases, the natural environment, if they are not adequately purified $[14,15]$. Wipes have a textile weave composed mainly of polyester, cotton, and cellulose microfibers and are usually moistened with glycerin, which inhibits the action of bacteria responsible for the decomposition of these materials [16]. A study by Water UK [17], a body representing the UK's leading water and wastewater service providers, revealed that around $93 \%$ of the material causing clogs in sewerage systems is wet wipes and that only $1 \%$ of household waste is toilet paper. Additionally, a study conducted by OCU [18] warned that wipes are neither biodegradable nor disposable, and that they do not behave like wet toilet paper, as is sometimes indicated in the advertising of various brands; therefore, they should be considered solid waste and thrown in garbage containers.

Cabrera and García [19] point out that wet wipes and other hygienic products are of-ten flushed down the toilet due to lack of understanding, embarrassment, or the inappropriate labeling of the product, and thus end up flowing into the marine environment through the wastewater release system. Based on this situation, these authors stress the importance of raising awareness of the impacts of single-use sanitary and hygiene products, identifying existing solutions and highlighting their environmental, social, and economic advantages. From this perspective, a study by Del Rey et al. [20] indicated that environmental education programs key tools for improving knowledge, attitudes, and environmental perception of water-related problems and their impacts on aquatic ecosystems. However, educational research solidly demonstrates that knowledge of environmental problems is 
insufficient to stimulate pro-environmental behaviors [21,22]. In this sense, these authors indicate that environmental education should offer participatory and action-oriented learning opportunities that allow students to understand how their lifestyles and daily habits have a negative impact on the sustainability of natural environments.

\subsection{Cross-Sectoral Collaboration to Reduce the Impact of Hygiene Waste}

Microplastics derived from hygienic waste are a global problem that affects our society, people's health, and the environment. For this reason, different organizations, entities, and institutions must collaborate and participate jointly in proposing solutions. For example, the EU adopted a European strategy to reduce plastics in January 2018. The European Strategy for Plastics in a Circular Economy [23] is part of the EU's circular economy action plan and is based on a series of measures to prevent plastics from damaging our aquatic ecosystems. These measures aim to protect our environment and reduce marine litter, greenhouse gas emissions, and its dependence on imported fossil fuels through more sustainable and safer production and consumption patterns for plastics. The EU also works with international partners to design global solutions and set international standards for the use of plastics. Additionally, Klemeš et al. [24] highlight the importance of addressing the plastics problem through the promotion of the concept of circular economy, mainly by increasing user awareness and education, encouraging a reduction in the use of plastics (including redesign), and improving the life-cycle management of plastics.

From this perspective, the participation of manufacturers and companies in the sector plays a key role in the fight against microplastics. Some guidelines followed by industries to improve the management of these wastes involve limitations on their use, a reduction in their consumption, the prevention of damage from plastic spills through the use of proper and truthful labeling, environmental liability regimes (complying with the polluter pays principle), awareness campaigns, and new technical requirements for the eco-design of products. Industry commitment and compliance with codes of good practice are, therefore, essential for mitigating the environmental and economic impacts of hygiene waste [25].

Environmental organizations (Greenpeace, Ecologists in Action, etc.) have proposed educational actions through the design and implementation of training and awareness campaigns for citizens, companies, and governments, using prevention and social participation as the main measures to reduce the high amount of plastic hygiene products entering in natural environments. For example, the "Clean Seas" campaign of the United Nations Environment Program (UNEP), in which more than 63 countries are participating, aims to combat marine litter and plastic pollution through public awareness activities. This campaign is led by the Global Alliance on Marine Litter and brings together all sectors, from policy makers to industries and individuals, to commit to reducing the consumption of disposable plastic. Its goals focus on compliance with the " $4 \mathrm{Rs}$ " motto: reduce, reuse, recycle, and repair. According to the UN Environment's "Biodegradable Plastics" report, many people are attracted to "technological solutions as an alternative to change behavior". In this regard, entrepreneurs, large companies, and researchers have been creating a wide variety of biodegradable and/or compostable plastic substitutes for more than 20 years. However, innovation, research, and technology are not sufficient to reverse these impacts if we do not change our behaviors and lifestyles to reduce our plastic footprint [26]. Scientific and research institutes also warn of the importance of obtaining data to develop a protocol for the sampling and analysis of microplastics to determine the environmental impact on aquatic ecosystems [16].

Similarly, public entities and institutions play key roles in the development of actions that contribute to the maintenance of an efficient water purification system and sanitation networks that prevent toilet waste from contaminating aquifers and the marine environment. They are also responsible for implementing legislative changes and technical standards that enable manufacturers, distributors, and the administrations themselves to assume commitments and responsibilities with respect to the management of these products. An example of this is the Draft Law on Waste and Contaminated Soils, promoted by 
the Spanish Ministry for Ecological Transition and the Demographic Challenge [27], aimed at limiting the consumption of single-use plastic. This law includes marking obligations for wipes, the development of extended producer responsibility by 2025 , and the implementation of awareness-raising measures to inform consumers of their negative impact on the environment. This law gives a leading role to prevention, reuse, and recycling, which are essential elements in promoting a circular and low-carbon economy.

It is, therefore, essential to combine the efforts of these different sectors and involve public and private actors in carrying out awareness-raising activities and making meaningful proposals for action to enable citizens and stakeholders to manage waste more consciously, appropriately, and responsibly. It should be remembered that it is not a question of finding culprits, but of proposing solutions.

\subsection{The Environmental Education Program "Yo sí cuido el Agua" ("I Do Care for Water") as an Engine of Change}

In the university educational field, the research and evaluation of the effectiveness of stable environmental education programs, which present continuity of more than three years, is considered fundamental. In this regard, the results of a study conducted by Zhan et al. [28] on the effectiveness of an EA program concerning water conservation indicated that the length of time the program was in place was one of the factors that most influenced behavior change. In addition, they found that the involvement and participation of the different educational agents in the design and implementation of the program was key to the acquisition of pro-environmental behaviors. This is the case for the "I Do Care for Water" program, which focuses on the promotion of good citizen practices related to the responsible use of water and was implemented through an alliance between the administration, companies, and social entities (environmental associations belonging to the "third sector"). Specifically, it is the result of a collaboration agreement between the Department of Environment and Sustainability of the Malaga City Council, the municipal water company (EMASA in Spanish acronyms), and the Association for the Conservation of the Marine Environment Aula del Mar de Malaga (Malaga Sea Classroom).

The program was initially called "The Toilet is not a Wastebasket". However, it was considered convenient to modify the focus of the messages and establish more positive communication to improve the version of the program. As a consequence, the title of this educational program was changed to "I Do Care for Water".

In this regard, Torres et al. [29] indicate that the focus of the message can influence the behaviors of young people. These authors point out that awareness campaigns are more successful in changing behaviors when they emphasize social norms rather than the importance of environmental protection. In other words, it seems that people adopt certain pro-environmental behaviors when they believe that members of their own social group also develop behaviors of respect and care for the environment. Goldstein, Cialdini, and Griskevicius $[30,31]$ analyzed hotel guests' behaviors regarding reusing room towels based on two different types of messages. They found that the environmental message "Help save the environment" produced less impact than the social message "Join your fellow guests to help save the environment", with which they persuaded 75\% of guests to reuse their towels. Thus, the program's new title and message, "I Do Care for Water", also aims to convey the existence of a social norm and collective awareness of the problem of hygienic waste.

This is an educational and innovative impact action aimed at educational centers in the Municipality of Malaga aiming to minimize the disposal of personal hygiene waste, wet wipes, and other plastic waste into domestic drains, which hinders the proper purification of wastewater and alters the environmental quality of ecosystem waters, thus negatively affecting the ecological and economic value of the coastline. Although different types of infrastructure and cutting-edge technology are currently available for wastewater treatment, it is important to raise awareness and promote good citizen practices regarding the use of water and the proper disposal of waste in order to optimize their operation. To this end, Benninghaus et al. [32] argue that sustainability-oriented education must include all 
three dimensions (environmental, social and economic) equally to explain the impacts of socio-environmental problems. An exclusive consideration of the environmental dimension is insufficient to promote a comprehensive understanding of sustainable development.

This educational program aims to promote a culture of environmental sustainability and raise awareness in the educational community as one of its primary steps. It also aims to connect with the general population, indicating the responsibility we all have for preserving the quality of such an essential resource for life as water. It is especially important to recognize daily behaviors that favor a reduction in the amount of hygienic waste that reaches the coastal environment through domestic drains. In this sense, Amahmid et al. [33] point out that, in order to change students' attitudes and behaviors towards water use and conservation, the water-related contents should be taught in an accessible and experiential way, using a values-based education, innovative and technology-based learning methodologies.

For the design of this environmental education program, the "Aula del Mar" of Malaga relied on didactic resources related to the curricular subjects of Natural and Social Sciences, which are taught in primary and secondary education, with the intention of providing a useful tool for teachers of different educational levels that could be used in the teaching-learning process of their students. The program is directly aimed at students in the second and third cycles of primary education, but indirectly it is also aimed at their families and homes.

The environmental education program "I Do Care for Water" makes use of a participatory and interactive didactic methodology based on social and emotional learning, which encourages the personal and collective discovery of the sustainability problems associated with the misuse of domestic sewage and the lack of knowledge regarding the impacts on aquatic ecosystems.

The program of activities begins with an interactive digital presentation at the educational center, followed by a visit to a wastewater pumping station (WWTP) where different types of domestic hygienic waste are identified (Figure 1). Interactive workshops are held on the topic of the persistence of the negative effects of this waste on the aquatic environment and marine life (Figure 2).

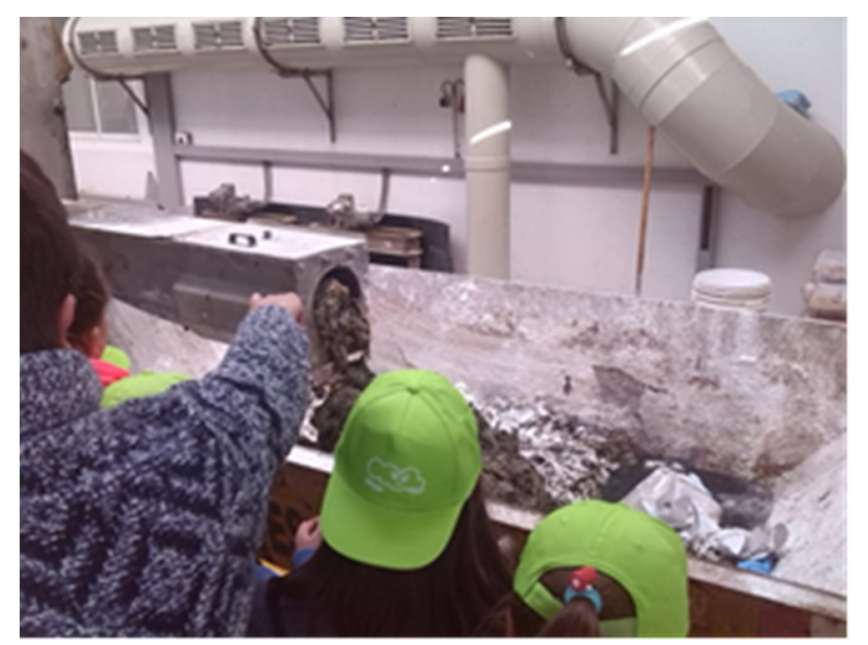

Figure 1. Educational visit to wastewater pumping station. Source: own elaboration. 


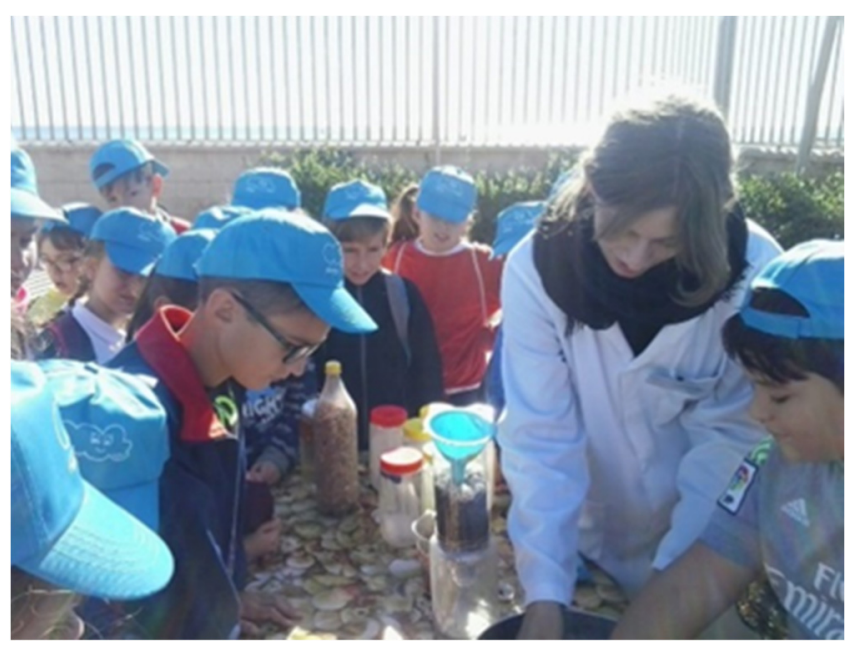

Figure 2. Experimental activity: identification of hygienic wastes and assessment of their effects on the aquatic environment. Source: own elaboration.

The activity is complemented by a coastal itinerary on an urban beach, where students are arranged in small groups to note the diversity of plastic hygienic waste of domestic origin and its abundance along certain stretches of coastline (Figure 3).

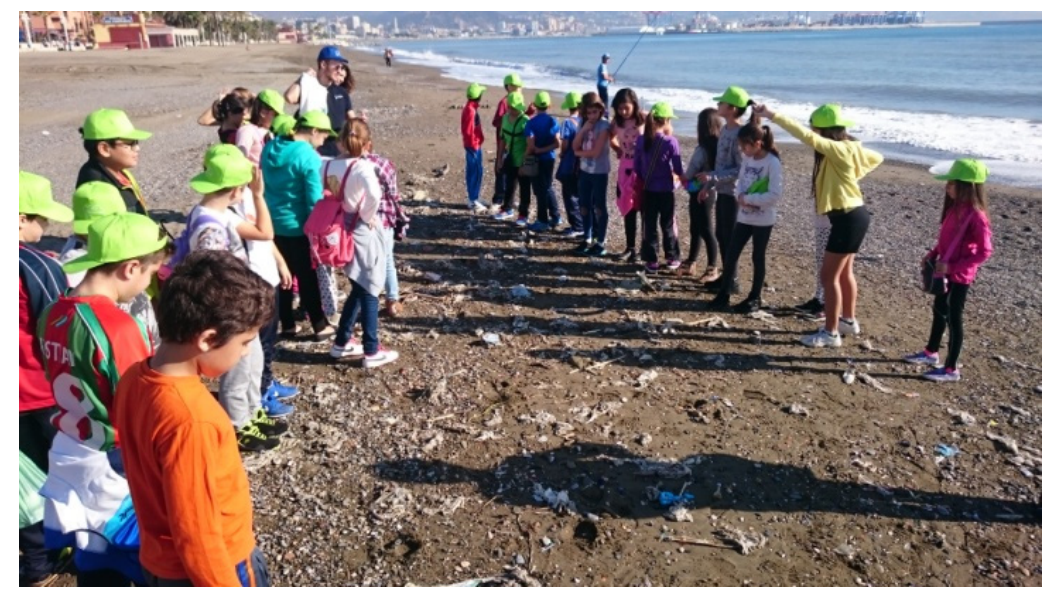

Figure 3. Coastal itinerary to identify debris and marine fauna remains. Source: own elaboration.

Finally, in the educational center, a dynamic of evaluation and realization of proposals or key solutions is carried out, to disseminate and promote good practices related to the proper management of sanitary and hygienic waste. Additionally, in this phase of the program, special emphasis is placed on students becoming agents of change, sharing and transmitting the experiences, emotions, and knowledge acquired during the program to the rest of the educational community, their friends, and their families. A study by Duarte et al. [34] indicates that the acquisition of pro-environmental attitudes by young people is the result of a complex interaction of many social factors-e.g., family background, school characteristics, school programs, and social interactions with peers. Specifically, they point out that there is evidence on the effects of the intergenerational transmission of environmental attitudes, with communication within the family being an important socializing factor that influences changes in the environmental attitudes of young people. They also point out that interactions among peers and friends reinforce the acquisition of attitudes.

This study focuses on the evaluation of the effectiveness of environmental awareness and education campaigns conducted with schoolchildren in relation to the achievement of the Sustainable Development Goals established by the United Nations (2020-2030) [35]. 
In particular, we focus on SDG \#17, "Partnerships between sectors", and SDG \#6, "Ensure availability and sustainable management of water and sanitation for all", which includes Target 6.B (support and strengthen the participation of local communities in improving water and sanitation management), Target 6.3 (water quality, pollution and wastewater), and Target 6.6 (protect and restore water-related ecosystems, including forests, mountains, wetlands, rivers, aquifers, and lakes). Water supply and sanitation services, as well as our use of water resources, are part of basic human needs. The UN-Water [36] warns that the water and sanitation crisis is worsening. UN Secretary General António Guterres stated that the lack of progress on SDG6 "undermines progress on all other goals, particularly global health, education, food, gender equality, energy and climate change" [37]. With this frame of reference, Education for Sustainable Development (ESD) considers the importance of including learning objectives (cognitive, behavioral and socio-emotional), content, competencies, and innovative methodological approaches that enable students to become aware of and act on water and sanitation issues, including integrated water resources management [38]. From this perspective, ESD also points out the need to incorporate informal and non-formal learning projects, campaigns, and environmental education programs to increase the awareness of the young population about the risks and socio-environmental consequences associated with inadequate water use and management.

\section{Objectives}

The general objective of this research was to know and analyze the effectiveness of the environmental education program "Yo sí cuido el agua" ("I Do Care for Water"), aimed at raising awareness among students of the second and third cycle of primary education about the socio-environmental impacts caused by the dumping of hygienic and sanitary waste in domestic drains on aquatic ecosystems.

The specific objectives of the research are as follows:

- To analyze the participants' prior knowledge of the causes and consequences of the misuse of domestic drains related to the disposal of sanitary and hygienic waste (wipes, swabs, compresses, oils, etc.);

- To determine the level of influence that participants can exert on their close social environment (family, friends, and acquaintances) after the application of the program;

- To explore and identify the emotions and pro-environmental behaviors that originate from participation in the program (feelings concerning the seriousness of the problem and the emotions aroused after participation in the program);

- To determine and assess the participants' willingness to act before and after the implementation of the program; and

- To analyze and compare the effectiveness of the two different versions of the program.

\section{Methodology}

A quantitative longitudinal study (5 years) was conducted using a survey methodology that included the design, validation, and application of a questionnaire-type instrument.

The instrument was constructed on the basis of an extensive review of the scientific literature that allowed us to design a first version of the questionnaire to respond to the objectives and research problem. Afterwards, the characteristics of the sample were determined in order to adapt the questionnaire to the particularities of the population analyzed (primary school students aged 8 to 12 years). Once the instrument was developed, it was subjected to validation by six experts in the field (environmental education and research methodology); subsequently, the reliability and validity of the measure obtained with the application of the questionnaire were analyzed. The analysis included a reliability study (internal consistency) based on Cronbach's Alpha coefficient, a factor analysis, and a categorical analysis of principal components (CATPCA), taking into account the ordinal and nominal nature of the data [39]. 


\subsection{Participants}

Expert sampling was performed [40] considering criteria that were essential for the research: (a) to be a student in middle or high school and (b) to actively participate in the program targeted by the evaluation. Thus, a sample of 4362 students was selected. We deliberately did not ask about the gender or sex of the students. The mean age of the students was 10.21 years $(\mathrm{SD}=1.05)$. In the Spanish educational system, primary education is structured into six grades and three cycles. The first cycle, or initial cycle, comprises the 1st and 2nd grades of primary education, with students being between 6 and 8 years of age. The second cycle, or middle cycle, comprises the 3rd and 4th grades of primary education, with students being between the ages of 8 and 10 . The third cycle, or upper cycle, comprises the 5th and 6th grades of primary education, with students being between 10 and 12 years of age. In this study, only students in the middle and upper (second and third) cycles of primary education (grades 3 to 6 , with students aged between 8 and 12 years) were considered (see Table 1).

Table 1. Distribution of the sample ordered by the annual campaigns of application of the program and cycles of primary education.

\begin{tabular}{|c|c|c|c|c|c|}
\hline Grades & Count & & Cycles of Primary Education & Count & \\
\hline $3 r d$ & 517 & $11.9 \%$ & \multirow{2}{*}{ 2nd/middle } & \multirow{2}{*}{2075} & \multirow[b]{2}{*}{$47.6 \%$} \\
\hline 4 th & 1558 & $35.7 \%$ & & & \\
\hline 5 th & 1240 & $28.4 \%$ & \multirow{2}{*}{ 3rd/upper } & \multirow{2}{*}{2287} & \multirow{2}{*}{$52.4 \%$} \\
\hline 6th & 1047 & $24.0 \%$ & & & \\
\hline Total & 4362 & $100.0 \%$ & 100.0 & 4362 & $100.0 \%$ \\
\hline
\end{tabular}

Source: own elaboration.

Students who participated in the first version of the program (Pv1: The Toilet is not a Wastebasket) accounted for $46.70 \%$ of the sample, while those who participated in the second version of the program, in which the focus and title of the program were changed (Pv2: I do care for water) accounted for $53.30 \%$. The program participants came from 71 schools in Malaga. The longitudinal study covered 5 years. Table 2 shows the different campaigns carried out between 2015 and 2019.

Table 2. Distribution of the sample ordered by the annual campaigns of application of the program and Program version.

\begin{tabular}{cccccc}
\hline Year Campaign & Count & & Program Version & Count \\
\hline 2015 & 714 & $16.4 \%$ & Pv1: The Toilet is not a Wastebasket & 2037 & $46.7 \%$ \\
2016 & 1323 & $30.3 \%$ & Pv2: I Do Care for Water & 2325 & $53.3 \%$ \\
2017 & 982 & $22.5 \%$ & & 4362 & $100.0 \%$ \\
2018 & 1144 & $26.2 \%$ & $4.6 \%$ & & \\
2019 & 199 & $100.0 \%$ & Source: own elaboration.
\end{tabular}

\subsection{Data Collection Instruments}

The questionnaire was organized on a Likert scale ranging from 1 to 3 (or to 4), and was organized based on the following dimensions following the proposal of Woosnam et al. [41], and Villamandos et al. [42]:

- Dimension 1: prior knowledge (cognitive level) about the consequences of the misuse of household drains (wipes, sanitary napkins, paper, oils...).

- Dimension 2: emotions (affective level) aroused by participation in the program (feelings concerning the seriousness of the problem and emotions aroused after participation in the program). 
- Dimension 3: willingness to act or change (conative level) before and after participation in the program.

The first column of Table 3 shows the variables used in the study organized by dimensions the language of the questionnaire was adapted to the age range and educational levels of Spanish-speaking the sample to which it was applied (8-12 years old).

Table 3. Ranges, means, and standard deviations of the items of the questionnaire.

\begin{tabular}{|c|c|c|c|}
\hline Variable/Level or Dimension & Range & Mean & Standard Deviation \\
\hline Severity of the problem/affective level & $1-3$ & 2.85 & 0.44 \\
\hline $\begin{array}{l}\text { Before the program, knowledge about the consequences of } \\
\text { disposing of various types of waste down household } \\
\text { drains/cognitive level }\end{array}$ & $1-4$ & 2.42 & 1.04 \\
\hline $\begin{array}{l}\text { Before the program, s/he used to throw these different types of } \\
\text { waste down the household drainage system/conative level }\end{array}$ & $1-4$ & 1.65 & 0.84 \\
\hline $\begin{array}{l}\text { After the program, whether s/he will continue to dispose of } \\
\text { these different types of waste down the household drainage } \\
\text { system/conative level }\end{array}$ & $1-3$ & 3.59 & 0.64 \\
\hline $\begin{array}{l}\text { Before the program, knowledge that used oil can be used to } \\
\text { make other products/cognitive level }\end{array}$ & $1-4$ & 2.40 & 1,15 \\
\hline $\begin{array}{l}\text { Before the program, knowledge about the harm done to the } \\
\text { environment by flushing certain wastes down household } \\
\text { drains/cognitive level }\end{array}$ & $1-4$ & 2.52 & 1.25 \\
\hline $\begin{array}{l}\text { Impression produced by the program on the } \\
\text { participant/affective level }\end{array}$ & $1-3$ & 2.81 & 0.50 \\
\hline
\end{tabular}

Source: own elaboration.

The questionnaire was structured in three parts:

1. Identification data (school, grade, and age);

2. Seven items on a scale (1 to 3 or 1 to 4 ), with three belonging to the cognitive level, two to the affective level, and two to the conative level;

3. Three categorical items, one (polytomous) to identify the breadth of the population to which the participants were going to transmit the information, and two (dichotomous) to know if the participants had a container in the bathroom for waste and if, after the program, they were going to ask their family to put it there.

Principal component factor analysis produced a three-factor model (consistent with the structure of the questionnaire) that explained $57.05 \%$ of the variability. After Varimax rotation with Kaiser normalization, the first factor (conative level) was formed by items 4,5 , and 9 of the questionnaire (Cronbach's alpha of 0.52 ) and explained $22.74 \%$ of the variance. The second factor (affective level) was formed by items 1 and $10(\alpha=0.80)$ and explained $17.89 \%$ of the variance. The third factor (cognitive level) was formed by items 3 and $8(\alpha=0.80)$ and explained $16.42 \%$ of the variance. The categorical analysis of principal components (CATPCA) confirmed this same structure of the seven-point scale items. The total Cronbach's alpha coefficient was 0.89 .

\subsection{Data Analysis}

Descriptive analyses-frequencies, percentages, means, and standard deviationswere performed and $t$-tests were conducted for all the items of the questionnaire, separately, for the two versions of the program (Pv1 and Pv2) and the cycle of primary education: middle cycle (3rd and 4th grades of primary education) and upper cycle (5th and 6th grades). In the same way, all the dependent variables (questionnaire items) and independent variables (versions of the program and primary education cycle) were included in a single design, for which a multivariate analysis of variance (MANOVA) was used. Multivariate analyses are more sensitive in detecting significant differences and also allow us to analyze the interaction between the independent variables. All quantitative data processing was carried out using the SPSS v24 statistical analysis package. As some of the 
items had a different range, corresponding changes in scale and standard normalization were carried out so that the different types of analysis could be applied.

\section{Results}

This section presents the results obtained. Firstly, the descriptive results are shown; secondly, the results of the bivariate analyses are presented-mainly comparisons of measures based on $t$-tests. Finally, taking into account the previous results, a multivariate analysis of variance was conducted.

\subsection{Descriptive Results}

Table 3 shows the items of the questionnaire, the range of the scale, the mean values, and the standard deviations obtained.

As shown in Table 3, at the affective level the participants seemed to be very aware of the severity of the problem (mean $=2.85 \pm 0.44$ ), and, once the program had been carried out, they had a strong impression of it (mean $=2.81 \pm 0.50)$. At the conative level, the students did not recognize that they throw various types of waste down domestic drains (mean $=1.65 \pm 0.84$ ). In the same line, they clearly indicated that they will not continue to dispose of this type of waste in the same way (mean $=3.59 \pm 0.64$ ). At the cognitive level, the three questions refer to attitudes before the program. In all three, students did not show a great lack of knowledge about the various problems (means between 2.40 and 2.52) but had more dispersed data distributions than they did at the affective and conative levels (standard deviations between 1.04 and 1.25). These results point to the need for further investigation with more in-depth inferential analyses.

The descriptive results of other items of the questionnaire show results for who the students are going to tell about what they have learned from the program; the fact of having or not having a wastebasket in the bathroom; and if they, after the program, are going to tell their cohabiting family that they should get one (in case they do not have one).

In relation to whom they are going to tell what they have learned (see Table 4), the overall distribution of the sample shows that the cohabiting family is the main recipient of information about the program attended by the participants $(57.4 \%)$. This is followed by the category that brings together the cohabiting family and friends (21.6\%). Only a small percentage did not plan to tell anyone what they learned in the program $(2.2 \%)$. In the breakdowns according to primary education cycle, very similar distributions to the global one can be observed. Only the category of the cohabiting family stands out. In the case of older participants (age between 10 and 12 years, belonging to the upper cycle of primary education), the percentage increases to $62.4 \%$, compared to $51.9 \%$ in the case of participants in the middle cycle of primary education (8-10 years of age).

Table 4. Descriptive results for the item "To whom are you going to tell what you have learned?" and disaggregation by primary education cycle.

\begin{tabular}{|c|c|c|c|c|c|c|}
\hline \multirow{2}{*}{$\begin{array}{l}\text { Item 2: To Whom Are You Going } \\
\text { to Tell What You Have Learned? } \\
\text { Nobody }\end{array}$} & \multicolumn{2}{|c|}{ Global Sample } & \multicolumn{2}{|c|}{ Pv1 } & \multicolumn{2}{|c|}{ Pv2 } \\
\hline & 98 & $2.2 \%$ & 49 & $2.4 \%$ & 49 & $2.1 \%$ \\
\hline Friends & 159 & $3.6 \%$ & 93 & $4.50 \%$ & 66 & $2.9 \%$ \\
\hline Cohabiting family & 2503 & $57.4 \%$ & 1075 & $51.9 \%$ & 1428 & $62.4 \%$ \\
\hline Cohabiting family and friends & 942 & $21.6 \%$ & 510 & $24.6 \%$ & 432 & $18.9 \%$ \\
\hline Others & 68 & $1.6 \%$ & 33 & $1.6 \%$ & 35 & $1.5 \%$ \\
\hline Everybody & 589 & $13.5 \%$ & 312 & $15.1 \%$ & 277 & $12.1 \%$ \\
\hline $\mathrm{N} / \mathrm{A}$ & 3 & $0.1 \%$ & 3 & $0.1 \%$ & 0 & $0.0 \%$ \\
\hline Total & 4362 & $100 \%$ & 2075 & $100 \%$ & 2387 & $100 \%$ \\
\hline
\end{tabular}


In the case of the disaggregation by program version, two relevant facts are observed when compared with the distribution of the overall sample (see Table 5). The first one is in the cohabiting family category. In the second version of the program, the percentage increases to $65.2 \%$. That is, with the second version of the program, the participants tell even more to their cohabiting family what they have learned in the program. The second fact to highlight is with the category that combines the cohabiting family and friends. In this second case, the percentage in the second version of the program decreases to $13.9 \%$ (probably because a greater number of participants concentrate on telling what they have learned to their cohabiting family members).

Table 5. Descriptive results for the item "To whom are you going to tell what you have learned?" and disaggregation by Program version.

\begin{tabular}{|c|c|c|c|c|c|c|}
\hline \multirow{2}{*}{$\begin{array}{l}\text { Item 2: To Whom Are You Going } \\
\text { to Tell What You Have Learned? } \\
\text { Nobody }\end{array}$} & \multicolumn{2}{|c|}{ Global Sample } & \multicolumn{2}{|c|}{ Pv1 } & \multicolumn{2}{|c|}{ Pv2 } \\
\hline & 98 & $2.2 \%$ & 48 & $2.4 \%$ & 50 & $2.2 \%$ \\
\hline Friends & 159 & $3.6 \%$ & 62 & $3.0 \%$ & 97 & $4.2 \%$ \\
\hline Cohabiting family & 2503 & $57.4 \%$ & 986 & $48.5 \%$ & 1517 & $65.2 \%$ \\
\hline Cohabiting family and friends & 942 & $21.6 \% \%$ & 618 & $30.4 \%$ & 324 & $13.9 \%$ \\
\hline Others & 68 & $1.6 \%$ & 51 & $2.5 \%$ & 17 & $0.7 \%$ \\
\hline Everybody & 589 & $13.5 \%$ & 269 & $13.2 \%$ & 320 & $13.8 \%$ \\
\hline $\mathrm{N} / \mathrm{A}$ & 3 & $0.1 \%$ & 3 & $0.1 \%$ & 0 & $0.0 \%$ \\
\hline Total & 4362 & $100 \%$ & 2037 & $100 \%$ & 2325 & 100 \\
\hline
\end{tabular}

Regarding whether or not they have a wastebasket in the bathroom, 71.2\% (3106 participants) indicated that they did. For participants who did not have one or did not use it properly, the majority indicated that, after the program, they would tell their families to either purchase one for the bathroom or to make use of the existing one $(90.8 \%)$.

\subsection{Bivariate Analysis}

To deepen the descriptive analyses, several bivariate analyses were performed depending on the characteristics of the data. With the nominal variables, cross-table analyses were performed (tests $\chi^{2}$ and contingency coefficients) relating the variables "to whom would you tell what you learned" (polytomous), whether or not they had a wastebasket in the bathroom (dichotomous), and whether they would ask their family to put a wastebasket (dichotomous) with the "educational cycle" and "version of the program". In all cases, the results were not significantly different from the overall sample. That is to say that the distributions for the disaggregated data in the case of educational cycle and program version were the same as those for the overall sample. However, when the rest of the questionnaire items were related to educational cycle and program version through $t$-tests, some significant results were obtained.

As shown in Table 6, the two items of the affective level show significant results. For both the severity of the problem $(t=-2.33$, with $4199.0 \mathrm{df}$ and $p=0.020)$ and the impression produced by the program $(t=-2.44$, with $4212.9 \mathrm{df}$ and $p=0.015)$, it is observed that the participants in the upper cycle of primary education (10-12 years) have been significantly more emotionally influenced than the younger ones (middle cycle of primary education, 8-10 years). Two other significant results stand out in Table 6: one at the cognitive level and the other at the conative level. It is possible that both results are related. Students in the upper cycle (10-12 years old), before the program, were slightly less aware of the damage that certain wastes did to the environment $(t=2.84$, with $4314.0 \mathrm{df}$ and $p=0.005)$. These same participants, after the completion of the program, seemed more willing to stop flushing such waste down the drain $(t=-3.77$, with $4347 \mathrm{df}$ and $p=0.001)$. The reading of these results seems to indicate that, after learning from participation in the program, 
students in the upper cycle of primary education (10-12) are more willing to act more pro-environmentally by not flushing certain waste down their household drains.

Table 6. $T$-tests between the items of the questionnaire (IV) and the cycle (middle or upper) of primary education (DV).

\begin{tabular}{|c|c|c|c|c|}
\hline Variable/Level or Dimension & $t$ & df & $p$ & $\begin{array}{l}\text { Middle Cycle Mean } \\
\text { Upper Cycle Mean }\end{array}$ \\
\hline Severity of the problem/affective level & $-2.33 *$ & 4199.0 & 0.020 & $\begin{array}{l}2.83 \\
2.86\end{array}$ \\
\hline $\begin{array}{l}\text { Before the program, knowledge about the } \\
\text { consequences of disposing of various types of } \\
\text { waste down household drains/cognitive level }\end{array}$ & $0.25 *$ & 4199.0 & 0.800 & $\begin{array}{l}2.42 \\
2.42\end{array}$ \\
\hline $\begin{array}{l}\text { Before the program, s/he used to throw these } \\
\text { different types of waste down the household } \\
\text { drainage system/conative level }\end{array}$ & -0.24 & 4345.0 & 0.813 & $\begin{array}{l}1.65 \\
1.66\end{array}$ \\
\hline $\begin{array}{l}\text { After the program, whether s/he will continue to } \\
\text { dispose of these different types of waste down the } \\
\text { household drainage system/conative level }\end{array}$ & -3.37 & 4347.0 & 0.001 & $\begin{array}{l}3.55 \\
3.62\end{array}$ \\
\hline $\begin{array}{l}\text { Before the program, knowledge that used oil can be } \\
\text { used to make other products/cognitive level }\end{array}$ & 0.00 & 4335.0 & 0.998 & $\begin{array}{l}2.40 \\
2.40\end{array}$ \\
\hline $\begin{array}{l}\text { Before the program, knowledge about the harm } \\
\text { done to the environment by flushing certain wastes } \\
\text { down household drains/cognitive level }\end{array}$ & $2.84^{*}$ & 4314.0 & 0.005 & $\begin{array}{l}2.57 \\
2.47\end{array}$ \\
\hline $\begin{array}{l}\text { Impression produced by the program on the } \\
\text { participant/affective level }\end{array}$ & $-2.44^{*}$ & 4212.9 & 0.015 & $\begin{array}{l}2.79 \\
2.83\end{array}$ \\
\hline
\end{tabular}

${ }^{*}$ A corrected $t$-value has been used because homoscedasticity of variances is not satisfied. Source: own elaboration.

When the items of the questionnaire and the versions of the program are related, significant differences are observed in all the items of the cognitive- and conative (but not affective) -level scales (Table 7). The most relevant result is related to the behavior of continuing to throw various types of waste down the drain after having completed the program: the participants who have completed the second version of the program are categorically more against continuing to throw waste down drains $(t=-37.07$, with $3431.4 \mathrm{df}$ and $p<0.0005)$. This result can be interpreted as a clear mark of the success of the second version of the program.

Table 7. $t$-tests between the items of the questionnaire (IV) and program version (DV).

\begin{tabular}{|c|c|c|c|c|}
\hline Variable/Level or Dimension & $t$ & df & $p$ & $\begin{array}{l}\text { Pv1 Mean } \\
\text { Pv2 Mean }\end{array}$ \\
\hline Severity of the problem/affective level & $1.66^{*}$ & 4357.7 & 0.099 & $\begin{array}{l}2.86 \\
2.84\end{array}$ \\
\hline $\begin{array}{l}\text { Before the program, knowledge about the } \\
\text { consequences of disposing of various types of } \\
\text { waste down household drains/cognitive level }\end{array}$ & $-6.70 *$ & 4088.6 & 0.000 & $\begin{array}{l}2.31 \\
2.52\end{array}$ \\
\hline $\begin{array}{l}\text { Before the program, s/he used to throw these } \\
\text { different types of waste down the household } \\
\text { drainage system/conative level }\end{array}$ & 7.89 & 4345.0 & 0.000 & $\begin{array}{l}1.76 \\
1.56\end{array}$ \\
\hline $\begin{array}{l}\text { After the program, whether s/he will continue to } \\
\text { dispose of these different types of waste down the } \\
\text { household drainage system/conative level }\end{array}$ & $-37.07 *$ & 3431.4 & 0.000 & $\begin{array}{l}3.24 \\
3.89\end{array}$ \\
\hline $\begin{array}{l}\text { Before the program, knowledge that used oil can be } \\
\text { used to make other products/cognitive level }\end{array}$ & $9.12 *$ & 4279.2 & 0.000 & $\begin{array}{l}2.57 \\
2.26\end{array}$ \\
\hline $\begin{array}{l}\text { Before the program, knowledge about the harm } \\
\text { done to the environment by flushing certain wastes } \\
\text { down household drains/cognitive level }\end{array}$ & $-5.45^{*}$ & 4324.4 & 0.000 & $\begin{array}{l}2.41 \\
2.61\end{array}$ \\
\hline $\begin{array}{l}\text { Impression produced by the program on the } \\
\text { participant/affective level }\end{array}$ & $1.85^{*}$ & 4345.9 & 0.065 & $\begin{array}{l}2.83 \\
2.80\end{array}$ \\
\hline
\end{tabular}

* A corrected $t$-value has been used because homoscedasticity of variances is not satisfied. Source: own elaboration. 


\subsection{Multivariate Analysis}

Based on the information obtained from the descriptive and bivariate analyses, with the variables that the previous results indicated would be relevant, a multivariate analysis of variance (MANOVA) was performed. For this purpose, with the variables' cycle and program version (fixed factors) and with the scale items of the questionnaire (dependent variables), the Pillai trace, Wilks' Lambda, Hotelling's trace, and Roy's major root were calculated. The $F$ tests performed contrasted the multivariate effect by educational cycle, by program version, and by the interaction of both variables. The following table shows the contrasts to accept or reject the null hypotheses of independence. In addition, the calculation of the effect size from partial coefficient $\eta^{2}$ has been included.

Table 8 shows the relevance of the program version in the model (significant $p$-values with an effect size of 0.288 ). The educational cycle also has an influence (significant $p$-values, although with effect sizes of less than 0.029). However, if the intercept of the model is observed, the effect size rises to 0.991 . The intersubject effects tests performed again showed the relevance in the model of the program version and the educational cycle (all contrasts are significant, although the effect sizes are smaller in this second variable). Table 9 includes the tests of significant intersubject effects, including for each case the effect size. Although all significant contrasts are shown $(p<0.025)$, the effect sizes are small.

The results of these multivariate analyses (Table 9) seem to demonstrate the influence of the educational cycle and the change in program version on the effectiveness of the program. Going deeper into the results obtained in the bivariate analyses, the program seems to work a little better with students in the upper cycle (10-12 years) and in the second version of the program, although always with small differential effect sizes. In the interaction of both factors (educational cycle and version of the program), differences are only observed at the conative level after the program-that is, students in the upper cycle and with the most current version of the program will demonstrate better behavior by not throwing certain waste down domestic drains as opposed to students in the middle cycle with the initial version of the program $(F=31.09$, with $p<0.0005)$.

Table 8. MANOVA contrast tests.

\begin{tabular}{|c|c|c|c|c|c|c|c|}
\hline Effect & Test & Value & $F$ & Hypothesis df & Error df & $p$ & $\eta^{2}$ \\
\hline \multirow{4}{*}{ Interception } & Pillai trace & 0.991 & $65,797.5$ & 7 & 4299 & 0.000 & 0.991 \\
\hline & Wilks' Lambda & 0.009 & $65,797.5$ & 7 & 4299 & 0.000 & 0.991 \\
\hline & Hotelling's trace & 106.65 & $65,797.5$ & 7 & 4299 & 0.000 & 0.991 \\
\hline & Roy's mayor root & 106.65 & $65,797.5$ & 7 & 4299 & 0.000 & 0.991 \\
\hline \multirow{4}{*}{$\begin{array}{c}\text { Educational } \\
\text { Cycle }\end{array}$} & Pillai trace & 0.029 & 18.090 & 7 & 4299 & 0.000 & 0.029 \\
\hline & Wilks' Lambda & 0.971 & 18.090 & 7 & 4299 & 0.000 & 0.029 \\
\hline & Hotelling's trace & 0.029 & 18.090 & 7 & 4299 & 0.000 & 0.029 \\
\hline & Roy's mayor root & 0.029 & 18.090 & 7 & 4299 & 0.000 & 0.029 \\
\hline \multirow{4}{*}{$\begin{array}{l}\text { Program } \\
\text { version }\end{array}$} & Pillai trace & 0.288 & 18.090 & 7 & 4299 & 0.000 & 0.288 \\
\hline & Wilks' Lambda & 0.712 & 248.004 & 7 & 4299 & 0.000 & 0.288 \\
\hline & Hotelling's trace & 0.404 & 248.004 & 7 & 4299 & 0.000 & 0.288 \\
\hline & Roy's mayor root & 0.404 & 248.004 & 7 & 4299 & 0.000 & 0.288 \\
\hline \multirow{2}{*}{$\begin{array}{c}\text { Educational } \\
\text { cycle X }\end{array}$} & Pillai trace & 0.009 & 5.409 & 7 & 4299 & 0.000 & 0.009 \\
\hline & Wilks' Lambda & 0.991 & 5.409 & 7 & 4299 & 0.000 & 0.009 \\
\hline \multirow{2}{*}{$\begin{array}{l}\text { Program } \\
\text { version }\end{array}$} & Hotelling's trace & 0.009 & 5.409 & 7 & 4299 & 0.000 & 0.009 \\
\hline & Roy's mayor root & 0.009 & 5.409 & 7 & 4299 & 0.000 & 0.009 \\
\hline
\end{tabular}


Table 9. Tests of intersubject effects for educational cycle and program version.

\begin{tabular}{|c|c|c|c|c|}
\hline & Variable/Dimensión & $F$ & $p$ & $\eta^{2}$ \\
\hline \multirow[t]{8}{*}{ Educational cycle } & Severity of the problem/affective level & 8.35 & 0.004 & 0.002 \\
\hline & Before the program, knowledge about the consequences & & & \\
\hline & $\begin{array}{l}\text { of disposing of various types of waste down household } \\
\text { drains/cognitive level }\end{array}$ & 6.79 & 0.009 & 0.002 \\
\hline & $\begin{array}{l}\text { Before the program, s/he used to throw these different } \\
\text { types of waste down the household drainage } \\
\text { system/conative level }\end{array}$ & 8.03 & 0.005 & 0.002 \\
\hline & $\begin{array}{l}\text { After the program, whether s/he will continue to dispose } \\
\text { of these different types of waste down the household } \\
\text { drainage system/conative level }\end{array}$ & 76.53 & 0.000 & 0.017 \\
\hline & $\begin{array}{l}\text { Before the program, knowledge that used oil can be used } \\
\text { to make other products/cognitive level }\end{array}$ & 8.10 & 0.004 & 0.002 \\
\hline & $\begin{array}{l}\text { Before the program, knowledge about the harm done to } \\
\text { the environment by flushing certain wastes down } \\
\text { household drains / cognitive level }\end{array}$ & 24.07 & 0.000 & 0.006 \\
\hline & $\begin{array}{l}\text { Impression produced by the program on the } \\
\text { participant/affective level }\end{array}$ & 10.39 & 0.010 & 0.002 \\
\hline \multirow[t]{7}{*}{ Program Version } & Severity of the problem/affective level & 6.58 & 0.000 & 0.002 \\
\hline & $\begin{array}{l}\text { Before the program, knowledge about the consequences } \\
\text { of disposing of various types of waste down household } \\
\text { drains/cognitive level }\end{array}$ & 51.28 & 0.000 & 0.012 \\
\hline & $\begin{array}{l}\text { Before the program, s/he used to throw these different } \\
\text { types of waste down the household drainage } \\
\text { system/conative level }\end{array}$ & 72.07 & 0.000 & 0.016 \\
\hline & $\begin{array}{l}\text { After the program, whether s/he will continue to dispose } \\
\text { of these different types of waste down the household } \\
\text { drainage system/conative level }\end{array}$ & 1557.9 & 0.000 & 0.266 \\
\hline & $\begin{array}{l}\text { Before the program, knowledge that used oil can be used } \\
\text { to make other products/cognitive level }\end{array}$ & 90.83 & 0.000 & 0.021 \\
\hline & $\begin{array}{l}\text { Before the program, knowledge about the harm done to } \\
\text { the environment by flushing certain wastes down } \\
\text { household drains/cognitive level }\end{array}$ & 43.68 & 0.000 & 0.010 \\
\hline & $\begin{array}{l}\text { Impression produced by the program on the } \\
\text { participant/affective level }\end{array}$ & 8.32 & 0.004 & 0.002 \\
\hline $\begin{array}{l}\text { Educational cycle } \\
\qquad X\end{array}$ & Severity of the problem/affective level & 0.003 & 0.954 & 0.000 \\
\hline \multirow[t]{6}{*}{ Program version } & $\begin{array}{l}\text { Before the program, knowledge about the consequences } \\
\text { of disposing of various types of waste down household } \\
\text { drains/cognitive level }\end{array}$ & 1.41 & 0.235 & 0.000 \\
\hline & $\begin{array}{l}\text { Before the program, s/he used to throw these different } \\
\text { types of waste down the household drainage } \\
\text { system/conative level }\end{array}$ & 0.050 & 0.824 & 0.000 \\
\hline & $\begin{array}{l}\text { After the program, whether s/he will continue to dispose } \\
\text { of these different types of waste down the household } \\
\text { drainage system/conative level }\end{array}$ & 31.09 & 0.000 & 0.007 \\
\hline & $\begin{array}{l}\text { Before the program, knowledge that used oil can be used } \\
\text { to make other products/cognitive level }\end{array}$ & 1.83 & 0.176 & 0.000 \\
\hline & $\begin{array}{l}\text { Before the program, knowledge about the harm done to } \\
\text { the environment by flushing certain wastes down } \\
\text { household drains/cognitive level }\end{array}$ & 0.976 & 0.323 & 0.000 \\
\hline & $\begin{array}{l}\text { Impression produced by the program on the } \\
\text { participant/affective level }\end{array}$ & 0.096 & 0.757 & 0.000 \\
\hline
\end{tabular}

Source: own elaboration.

\section{Discussion and Conclusions}

In recent years, there has been growing interest and debate regarding the impacts arising from the production, consumption, and disposal of single-use hygienic products and plastic compounds. From the field of education, topic that has come to be of special relevance is the combatting of the problems of pollution and marine litter on our coasts deriving from the misuse of household drains [43]. A study carried out by Pozo et al. [44] indicates that students in the second and third cycle of EP do not seem to have a great knowledge of the processes involved in the urban water route, such as catchment, transport, and sanitation. Covitt et al. [45] also found that they had trouble identifying the elements and connections of water systems, as well as water-treatment systems. This circumstance 
points to the difficulty students may have in linking water with environmental care and the reasons for pollution [46]. From this perspective, this program helps to raise awareness of the functioning of water treatment systems and of the various environmental problems resulting from poor water management and care [47].

The evaluation of this environmental education program based on the principles of sustainability from a cross-sectoral approach allows us to determine and analyze the knowledge and attitudes that have been generated in the participating students [48]. In this regard, the Global Water Partnership (GWP), whose focus is the achievement of the SDGs, points out that it is essential to create alliances between different stakeholders (SDG 17) in order to obtain improvements in the management of water resources (SDG, 6). To this end, the GWP assumes that, although water-related problems are context-specific, the solutions are similar and should involve cross-sectoral cooperation, stakeholder information, reliable information, institutional capacity building, and transparency in decision making (SDG 17) [49].

With respect to the emotional impact that the program was intended to have on the participants, the results indicate that a high percentage of students were impressed by this activity. The participants, during their visit to the sewage pumping stations, were able to visually identify the different types of domestic hygienic waste and confirm its sewage origin through their sense of smell. Ollero [50] also indicates that the use of more than one sense to sensitize people has a greater impact on their discovery of natural phenomena and attitudes towards conservation.

A large percentage of the participants planned to tell their family members what they had learned. Therefore, the choice of the age group (8-12 years old) as the target of the environmental education program seems to be very appropriate. At these ages, there is usually good communication with families, allowing participants to exchange and transmit pro-environmental behaviors and values [51]. This longitudinal study was conducted over 5 years, from the 2014-2015 to the 2018-2019 school years, and indicates that the percentage of students who responded who do not have a garbage can in their bathroom at home, which is fundamental to avoiding the disposal of hygienic plastic waste through the toilet, decreases progressively over time. This result demonstrates the influence of the students participating in this program on the change in the behavior of their parents, favoring the transformation of values and habits that promote the sustainable management of hygienic waste. In this sense, Torres et al. [29], indicate that young people have great potential to act as agents of change and raise awareness of environmental problems.

Additionally, the high percentage of students who answered that they would tell their friends about the program was noteworthy. Environmental awareness among peers and the need to take co-responsibility for acting individually and collectively in a sustainable manner are highly relevant issues.

In addition, these results highlight the importance of the annual continuity of thematic environmental education programs in order to determine the effectiveness of their objectives, the progress made in terms of awareness, and possible improvements that could be incorporated. In this sense, Greenpeace [52] points out that carrying out punctual actions, such as cleaning the coastline, does not stop pollution because it is a punctual solution. While these actions contribute to reducing plastic waste problems, they do not tackle the source of the problem and ignore the unseen plastic pollution in the form of microplastics.

The questions relating to the students' previous knowledge of this environmental problem and their perception of the seriousness or repercussions of not using domestic wastewater responsibly also suggest some conclusions. Most of the actions that have a negative impact on sustainability occur as a consequence of a high deficit of environmental education in vital aspects of citizens' daily behaviors [53]. In other words, the preventive aspect of environmental education that affects the root of sustainability problems is important, since correcting their effects can be very costly economically and even produce irreversible alterations to ecosystems. In this sense, Torres et al. [29] indicate that implementing preventive environmental education programs can shape individual behaviors 
and increase the capacity and motivation of people to adopt behaviors and attitudes favorable to care and respect for the environment. A study conducted by Zhan et al. [28] revealed that many environmental education programs have contributed to the improvement of students' knowledge and commitment to water conservation, although they warn that only a few works have reported conclusive results in terms of self-efficacy and actions. In this sense, the results of this study indicate that this program contributes to acquiring a predisposition to action, since almost all the students who acknowledged having thrown plastic hygienic waste down the toilet affirmed that they would not continue to do so. From this perspective, we insist on the message that every small aspect in our hygiene habits has a direct impact on the care and protection of the natural environment.

Environmental education, defined in the "White Paper on Environmental Education in Spain" as "education for action" [54], contributes to the development of a model of society based on the values and principles of sustainability and is focused on changes in attitudes and daily habits, such as the promotion of good citizenship practices. In this sense, the environmental education of young people is essential, not only to enable them to face the challenges of the future, but also because of the influence they exert on their relatives and close adults in the present, as stated in the white paper. A change in students' awareness can lead to the acquisition of new habits, behaviors, and attitudes in their families and close environments. In this regard, a study conducted by Ablak and Yeşiltaş [55] on a sample of 524 high school students in Turkey reveals that talking to one's family about relevant aspects of environmental education increases the level of environmental awareness of students and households.

Despite the attention paid to the plastic crisis by the media and environmental campaigns, much of the practice surrounding single-use plastic has remained almost unchanged [56]. This demonstrates that progress towards change cannot be made without a common commitment from all sectors involved to reverse the impacts of human action.

The results of this study show the effectiveness of the program by valuing its preventive nature, the commitment of all key players involved in the management of hygienic waste, and the experiential teaching methodology based on reflection on our lifestyles. It also acts as a call to action to modify our behaviors and acquire attitudes that are beneficial for the conservation of our aquatic ecosystems.

Author Contributions: Conceptualization, L.-C.V.-M. and J.-C.T.-H.; methodology, J.-C.T.-H.; validation, L.-C.V.-M., J.-J.M.-J. and J.-C.T.-H.; formal analysis, J.-C.T.-H.; investigation, L.-C.V.-M. and J.-J.M.-J.; resources, L.-C.V.-M. and J.-J.M.-J.; data curation, J.-C.T.-H.; writing-original draft preparation, L.-C.V.-M. and J.-C.T.-H.; writing-review and editing, L.-C.V.-M., J.-J.M.-J., and L.-C.V.-M.; supervision, J.-C.T.-H. All authors have read and agreed to the published version of the manuscript.

Funding: This research received no external funding.

Institutional Review Board Statement: The study was conducted according to the guidelines of the Declaration of Helsinki, and approved by the Bioethics and Biosafety Committee of Universidad de Extremadura (File No. 158/2021 approved in 2021).

Informed Consent Statement: Informed consent was obtained from all subjects involved in the study. Data Availability Statement: Not applicable.

Acknowledgments: Malaga City Council, Department of Environment and Sustainability of the Malaga City Council, the municipal water company (EMASA, in Spanish acronyms), and the Association for the Conservation of the Marine Environment Aula del Mar de Malaga (Malaga Sea Classroom), responsible for the environmental education program "Yo sí cuido el agua" (I Do Care for Water).

Conflicts of Interest: The authors declare no conflict of interest. 


\section{References}

1. Barrows, A.P.; Cathey, S.E.; Petersen, C.W. Marine environment microfiber contamination: Global patterns and the diversity of microparticle origins. Environ. Pollut. 2018, 237, 275-284. [CrossRef]

2. Frias, J.P.; Nash, R. Microplastics: Finding a consensus on the definition. Mar. Pollut. Bull. 2019, 138, 145-147. [CrossRef]

3. AEAS. Microplásticos en Aguas de Consumo. Asociación Española de Abastecimientos de Agua y Saneamiento (AEAS). Madrid, España. 2021. Available online: https://revista.une.org/35/microplasticos-en-aguas-de-consumo.html (accessed on 29 October 2021).

4. Toussaint, B.; Raffael, B.; Angers-Loustau, A.; Gilliland, D.; Kestens, V.; Petrillo, M.; Rio-Echevarria, I.M.; Van den Eede, G. Review of micro- and nanoplastic contamination in the food chain. Food Addit. Contam. 2019, 36, 639-673. [CrossRef]

5. Walkinshaw, C.; Lindeque, P.K.; Thompson, R.; Tolhurst, T.; Cole, M. Microplastics and seafood: Lower trophic organisms at highest risk of contamination. Ecotoxicol. Environ. Saf. 2020, 190, 110066. [CrossRef]

6. Lusher, A. Microplastics in the Marin environment: Distribution, interacctions and effects. In Marine Anthropogenic Litter, 2nd ed.; Bergman, M., Gutow, L., Klages, M., Eds.; Springer: Chan, Switzerland, 2015; pp. 245-307.

7. Lindeque, P.; Cole, M.; Coppock, R.; Lewis, C.; Miller, R.; Watts, A.; Wilson-McNeal, A.; Stephanie, L.; Wright, S.; Galloway, T. Are we underestimating microplastic abundance in the marine environment? A comparison of microplastic capture with nets of different mesh-size. Environ. Pollut. 2020, 265, 114721. [CrossRef] [PubMed]

8. Rochman, C.M.; Tahir, A.; Williams, S.L.; Baxa, D.V.; Lam, R.; Miller, J.T.; Teh, F.C.; Werorilangi, S.; Teh, S.J. Anthropogenic debris in seafood: Plastic debris and fibers from textiles in fish and bivalves sold for human consumption. Sci. Rep. 2015, 5, 14340. [CrossRef]

9. Baqueiro, E.R.; Borabe, L.; Goldaracena, C.G.; Rodríguez, J. Los moluscos y la contaminación. Una revisión. Revista Mexicana de Biodiversidad 2007, 78, 1S-7S.

10. Besseling, E.; Redondo-Hasselerharm, P.; Foekema, E.M.; Koelmans, A.A. Quantifying ecological risks of aquatic micro- and nanoplastic. Crit. Rev. Environ. Sci. Technol. 2019, 49, 32-80. [CrossRef]

11. Nelms, S.; Barnett, J.; Brownlow, A.; Davison, N.; Deaville, R.; Galloway, T.; Lindeke, P.; Santillo, D.; Godley, B. Microplastics in Marine mammals stranded around the british coast: Ubiquitous but transitory? Sci. Rep. 2019, 9, 1075. [CrossRef]

12. Alomar, C.; Deudero, S.; Compa, M.; Guijarro, B. Exploring the relation between plastic ingestion in species and its presence in seafloor bottoms. Mar. Pollut. Bull. 2020, 160, 111641. [CrossRef] [PubMed]

13. Hantoro, I.; Löhr, A.J.; Van Belleghem, F.G.A.J.; Widianarko, B.; Ragas, A.M.J. Microplastics in coastal areas and seafood: Implications for food safety. Food Addit. Contam. 2019, 36, 674-711. [CrossRef] [PubMed]

14. Libera. Informe Libera. Tirando de la Cadena de la Higiene Personal: La Naturaleza como Retrete; del Retrete al Entorno; SEO/Birdlife y Ecoembes: Madrid, España, 2019; pp. 1-33.

15. Veiga, J.M.; Fleet, D.; Kinsey, S.; Nilsson, P.; Vlachogianni, T.; Werner, S.; Galgani, F.; Thompson, R.C.; Dagevos, J.; Gago, J.; et al. Identifying Sources of Marine Litter. MSFD GES TG Marine Litter Thematic Report; Publications Office of the European Union: Luxembourg, 2016; pp. 1-44.

16. Briain, O.O.; Marques, A.R.; Carron, S.M.; Healy, M.G.; Morrison, L. The role of wet wipes and sanitary towels as a source of white microplastic fibres in the marine environment. Water Res. 2020, 182, 116021. [CrossRef]

17. Water UK. Wipes in Sewer Blockage Study_Final Report; Water UK: London, UK, 2017; pp. 1-20.

18. Organización de Consumidores y Usuarios (OCU). Estudio Toallitas. Limpieza que ensucia. OCU-Compra Maestra 2016, $419,12-15$.

19. Cabrea, A.; García, R. The Environmental E Economic Cost of Single-Use Menstrual Products, Baby Nappies E Wet Wipes. Investigating the Impact of These Single-Use Items Across EUROPE; Zero Waste Europe (ZWE): Bruselas, Bélgica, 2019; pp. 1-65.

20. Del Rey, R.; Ojeda, M.; Mora-Merchán, J.A.; Sánchez-Díaz, M.N.; Morgado, B.; Lasaga, M.J. Environmental education: Effects on knowledge, attitudes and perceptions, and gender differences. Int. Res. Geogr. Environ. Educ. 2021. [CrossRef]

21. Bywater, K. Investigating the Benefits of Participatory Action Research for Environmental Education. Policy Futures Educ. 2014, 12, 920-932. [CrossRef]

22. Barata, R.; Castro, P.; Amélia Martins-Loução, M. How to promote conservation behaviours: The combined role of environmental education and commitment. Environ. Educ. Res. 2017, 23, 1322-1334. [CrossRef]

23. European Commission. A Europen Strategy for Plastics in a Circular Economy; European Commission: Bruxelas, Bélgica, 2018; pp. 1-24.

24. Klemeš, J.J.; Van Fan, Y.; Jiang, P. Plastics: Friends or foes? The circularity and plastic waste footprint. Energy Sources Part A Recovery Util. Environ. Eff. 2021, 43, 1549-1565. [CrossRef]

25. Asociación Nacional de Perfumería y Cosmética (STANPA). Código de Buenas Prácticas de Etiquetado de Toallitas y Papel Higiénico Húmedo. Un Compromiso del Sector Cosmético Para la Protección del Medio Ambiente; Stanpa: Madrid, España, 2019; pp. 1-12.

26. Organización de las Naciones Unidas (ONU). El Desafío de Vuelta a Clases. Comienza el. año Despidiéndote de los Plásticos Desechables; Clean Seas, ONU, IUCN: Bruselas, Bélgica, 2019; pp. 1-17.

27. Ministerio Para la Transición Ecológica y el Reto Demográfico. Proyecto de Ley 121/000056. Residuos y Suelos Contaminados. Boletín Oficial de las Cortes Generales, BOCG-14-A-57-1-C1, Gobierno de España, Madrid. 2021; pp. 1-128. Available online: https:/ / www.congreso.es/public_oficiales/L14/CONG/BOCG/A/BOCG-14-A-57-1-C1.PDF (accessed on 29 October 2021). 
28. Zhan, Y.; He, R.; Wing Mui So, W. Developing elementary school children's water conversation action competence: A case study in China. Int. J. Early Years Educ. 2019, 27, 287-305. [CrossRef]

29. Torres, H.R.; Reynolds, C.J.; Lewis, A.; Muller-Karger, F.; Alsharif, K.; Mastenbrook, K. Examining youth perceptions and social contexts of litter to improve marine debris environmental education. Environ. Educ. Res. 2019, 25, 1400-1415. [CrossRef]

30. Goldstein, N.J.; Cialdini, R.B.; Griskevicius, V. A room with a viewpoint: Using social norms to motivate environmental conservation in hotels. J. Consum. Res. 2008, 35, 472-482. [CrossRef]

31. Zaval, L.; Cornwell, J.F.M. Effective Education and Communication Strategies to Promote Environmental Engagement. Eur. J. Educ. 2017, 52, 477-486. [CrossRef]

32. Benninghaus, J.C.; Kremer, K.; Sprenger, S. Assessing high-school students' conceptions of global water consumption and sustainability. Int. Res. Geogr. Environ. Educ. 2018, 27, 250-266. [CrossRef]

33. Amahmid, O.; El Guamri, Y.; Yazidi, M.; Razoki, B.; Rassou, K.K.; Rakibi, Y.; Knini, G.; El Ouardi, T. Water education in school curricula: Impact on children knowledge, attitudes and behaviours towards water use. Int. Res. Geogr. Environ. Educ. 2019, 28, 178-193. [CrossRef]

34. Duarte, R.; Escario, J.J.; Sanagustín, M.V. The influence of the family, the school, and the group on the environmental attitudes of European students. Environ. Educ. Res. 2017, 23, 23-42. [CrossRef]

35. Organización de las Naciones Unidas (ONU). Transformar Nuestro Mundo: La Agenda 2030 para el Desarrollo Sostenible; ONU: Bruselas, Bélgica, 2015; pp. 1-40.

36. Organización de las Naciones Unidas (ONU). No dejar nadie atrás. Informe Mundial de las Naciones Unidas sobre el Desarrollo de los Recursos Hídricos. Organización de las Naciones Unidas para la Educación, la Ciencia y la Cultura, París, Francia. 2019. Available online: https: / www.acnur.org/5c93e4c34.pdf (accessed on 29 October 2021).

37. Organización de las Naciones Unidas-Agua (ONU-Agua). Foro Político de Alto Nivel Sobre el Desarrollo Sostenible Celebrado Bajo los Auspicios del Consejo Económico y Social. ONU, Bruselas, Bélgica. 2020. Available online: https://www.ohchr.org/SP/ Issues/SDGS/Pages/HighLevelPoliticalForum.aspx (accessed on 29 October 2021).

38. UNESCO. La Educación para los Objetivos de Desarrollo Sostenible. Organización de las Naciones Unidas para la Educación la Ciencia y la Cultura, París, Francia. 2017. Available online: https://web.unican.es/unidades/igualdad/SiteAssets/guia-derecursos/responsabilidad-social-universitaria/EdS_ODS.pdf (accessed on 29 October 2021).

39. Saukani, N.; Ismail, N.A. Identifying the Components of Social Capital by Categorical Principal Component Analysis (CATPCA). Soc. Indic. Re.s 2019, 141, 631-655. [CrossRef]

40. Etikan, I.; Bala, K. Sampling and Sampling Methods. Biometr. Biostat. 2017, 5, 00149. [CrossRef]

41. Woosnam, k.M.; Stylidis, D.; Ivkov, M. Explaining conative destination image through cognitive and affective destination image and emotional solidarity with residents. J. Sustain. Tour. 2020, 28, 917-935. [CrossRef]

42. Villamandos, F.; Gomera, A.; Antúnez, A. Conciencia ambiental y sostenibilización curricular, dos herramientas en el camino hacia la sostenibilidad de la Universidad de Córdoba. Rev. Educ. Ambient. Y Sostenibilidad 2019, 1, 1301. [CrossRef]

43. Jambeck, J.R.; Geyer, R.; Wilcox, C.; Siegler, T.R.; Perryman, M.; Andrady, A.; Narayan, R.; Law, K.L. Plastic waste inputs from land into the ocean. Science 2015, 347, 768-771. [CrossRef]

44. Pozo, M.P.; Velasco, L.C.; Martín, C.; Tójar, J.C. ¿Qué sabe el alumnado sobre las problemáticas socio-ambientales del agua y su gestión sostenible? Investigación mixta en Educación Primaria. REurEDC 2021, 18, 3501.

45. Covitt, B.A.; Gunckel, K.L.; Anderson, C.W. Students' developing understanding of water in environmental systems. J. Environ. Educ. 2009, 40, 37-51. [CrossRef]

46. Sari, H.N.; Karkkainen, S.; Tuula, K. Changes in primary school pupils' conceptions of water in the context of Science, Technology, and Society (STS) instruction. Int. Res. Geogr. Environ. Educ. 2018, 27, 118-134.

47. Moreira-Segura, C.; Araya-Rodríguez, F.; Charpentier-Esquivel, C. Educación ambiental para la conservación del recurso hídrico a partir del análisis estadístico de sus variables. Tecnología en Marcha 2015, 28, 74-85. [CrossRef]

48. Gutiérrez, J.; Benayas, J.; Calvo, S. Educación para el desarrollo sostenible: Evaluación de retos y oportunidades del decenio 2005-2014. Revista Iberoamericana de Educación 2006, 40, 25-69.

49. Organización de las Naciones Unidas (ONU). El Refuerzo y la Revitalización de las Alianzas Mundiales para Alcanzar el Objetivo de Desarrollo Sostenible 6: Tres Soluciones para Garantizar el Abastecimiento Seguro de Agua y Mantener el Crecimiento. ONU, Bruselas, Bélgica. 2019. Available online: https://www.un.org/es/chronicle/article/el-refuerzo-y-la-revitalizacion-de-lasalianzas-mundiales-para-alcanzar-el-objetivo-de-desarrollo (accessed on 29 October 2021).

50. Ollero, J.L. Somos Naturaleza. Metodología de lo Sensorial y Emocional en la Educación Ambiental; Organismo Autónomo Parques Nacionales. Ministerio de Medio Ambiente de España: Madrid, España, 2007; pp. 1-112.

51. Ministerio de Agricultura, Alimentación y Medio Ambiente (MAGRAMA). Programa Hogares Verdes; MAGRAMA: Madrid, España, 2014. Available online: https:/ /www.miteco.gob.es/es/ceneam/programas-de-educacion-ambiental/hogares-verdes/ que_es_h_v.aspx (accessed on 29 October 2021).

52. Greenpeace. Un Millón de Acciones Contra el Plástico; Greenpeace: Madrid, España, 2018; pp. 1-43.

53. Alonso- Sainz, T. Educación para el desarrollo sostenible: Una visión crítica desde la Pedagogía. Rev. Complut. Educ. 2021, 32, 249-259. [CrossRef]

54. Ministerio de Medio Ambiente. Libro Blanco de la Educación Ambiental en España; Ministerio de Medio Ambiente-Secretaría General de Medio Ambiente: Madrid, España, 1999; pp. 1-50. 
55. Ablak, S.; Yeşiltaş, E. Secondary School Students' Awareness of Environmental Education Concepts. RIGEO 2020, 10, 445-466. [CrossRef]

56. Rudman, S.; Rudman, L. Reconfiguring the everyday: Plastic waste as performance art in addressing the incongruity between the 'talk' and the 'walk' in the plastic crisis. Environ. Educ. Res. 2021, 27, 1487-1501. [CrossRef] 